Available online on 15.10 .2020 at http://jddtonline.info
OpDen Access to Pharmaceutical and Medical Research
unrestricted non-commercial use, provided the original work is properly cited

Open Access

Research Article

\title{
Knowledge Awareness and Attitude of Women toward Epidural Anesthesia during Labor
}

\author{
*Hatem A Hejaz, Khulood Skafe, Suzan Awawdeh \\ College of Pharmacy \& Medical Sciences, Hebron University, P.0. Box 40, Hebron-Palestine
}

\begin{abstract}
Background: Epidural analgesia is a central nerve block technique achieved by injection of a local anesthetic close to the nerves that transmit pain, and is widely used as a form of pain relief in labor. However, it is likely that epidural blocks lengthen labor and result in increased rates of operative vaginal delivery. Although, questions have been raised about its side effects.

Objectives: The aims of this research study are; to predict the common use of epidural analgesia in Palestinian women, to assess its effectiveness on pain relief, and to determine its adverse effects. However, the study designed to measure the knowledge awareness, and attitude of Palestinian women toward epidural anesthesia during labor.

Methods: A cross-sectional study was conducted using an online questionnaire. The study included females (age $<20$ - > 40 years old) from all governorates in Palestine. The survey was designed to measure the knowledge awareness and attitude of Palestinian women toward epidural anesthesia during labor. A total of 2685 females participated in the study. SPSS version 22 was used to analyze the data collected.

Results: About 893 women (33\%) participated in the research study didn't use the epidural analgesia and 1792 (67\%) women used it, out of 2685 women completed the questionnaire. The research study included Palestinian women in different Governorates in Palestine. 43.2 \% (800) of women who participated in this research study mentioned that the epidural injection is painless, 29.3\% (543) said that it is painful and others filled it may be painful. In women used epidural injection, the expending of uterus was $1-2 \mathrm{~cm}$ in 355 women $(20.5 \%), 2-3 \mathrm{~cm}$ in 325 women (18.7\%), 3-4 cm in 482 women (27.8\%), $4-5 \mathrm{~cm}$ in 355 women (20.5\%) and more than $5 \mathrm{~cm}$ in 218 women (12.6\%). The percentage of birth pain which anesthetized by epidural analgesia; 621 women (35\%) mentioned that the epidural injection anesthetized about 80-100\% , $24.5 \%(434)$ is $60-80 \%, 13 \%(230)$ is $40-60 \%, 9.4(166)$ is $20-40 \%$ and $18.2 \%$ (322) is $0-20 \%$. While 795 women (45.9\%) didn't have any difficulty pushing the fetus during delivery but $38.2 \%$ has a difficult push, and $15.9 \%$ said maybe they have. The most signs and symptoms mentioned are headache, backache, nausea, allergy at the site of injection, high body temperature, high blood sugar which a risk factor of diabetes, hypotension or hypertension in others, vomiting, tremor, itching, pain, and numbness in one or both legs, feeling cold, and absents of senses in the lower part for 12 hours after birth. Other results analysis such as; the frequency of uses epidural analgesia, the effects of child, and in which birth number they used it is included.
\end{abstract}

Conclusion: Epidural analgesia appears to be common in use in Palestinian women and effective in reducing pain during labor. The side eff ects of epidural analgesia on mother and child were found to be minor, but further research may be needed to evaluate rare but potentially severe adverse effects of epidural analgesia on women in labor and long-term neonatal outcomes. To the best of our knowledge, this is the first study about epidural analgesia in Palestinian women.

Keywords: Epidural Anesthesia; Labor, Delivery; Epidural analgesia; Local anesthetic

Article Info: Received 03 Aug 2020;

Review Completed 11 Sep 2020;

Accepted 17 Sep 2020;

Available online 15 Oct 2020

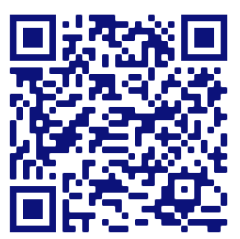

Cite this article as:

Hejaz HA, Skafe K, Awawdeh S, Knowledge Awareness and Attitude of Women toward Epidural Anesthesia during Labor, Journal of Drug Delivery and Therapeutics. 2020; 10(5-s):1-18 http://dx.doi.org/10.22270/jddt.v10i5-s.4333

*Address for Correspondence:

Dr. Hatem A Hejaz, College of Pharmacy \& Medical Sciences, Hebron University, P.O. Box 40, Hebron-Palestine. http://orcid.org/0000-0001-8757-133X

\section{INTRODUCTION}

The experience of labor is complex and subjective. Several factors affect a woman's perception of labor making each experience unique. However, as a consistent finding, labor pain is ranked high on the pain rating scale when compared to other painful life experiences ${ }^{1}$. The memory of this pain however is short-lived. The parturients who experienced severe pain in labor, $90 \%$ found the experience satisfactory three months later ${ }^{2}$. Women who seem to experience more intense pain during the pelvic phase of labor may as a result of sudden stimulation of nociceptors surrounding the vaginal vault, vulva, and perineum 3 , and rapid descent of the foetus ${ }^{4,5}$. Labour pain is a huge pain in mothers that any mothers can wish to remove and be easy.

Pain relief is an important issue for women in labor. The level of pain experienced and the effectiveness of pain relief may influence a woman's satisfaction with labor and 
birth. This also may have immediate and long-term emotional and psychological effects ${ }^{6}$. Several methods have been advocated to ease labor pain and different coping strategies, from limited intervention such as breathing exercises to medical techniques such as epidural analgesia. Epidural analgesia is a central nerve blockade technique, which involves the injection of a local anesthetic with or without an adjunct such as the opioid fentanyl, into the epidural space of the lower region of the spine close to the nerves that transmit painful stimuli from the contracting uterus and birth canal. Protocols for the care of women using epidural analgesia vary among hospitals. Epidural solutions are administered either by bolus, continuous infusion, or patient-controlled pump. An intermittent technique involves injections of local anesthetic through a catheter positioned in the epidural space. Boluses of higher concentrations, as used in the earlier years, have been associated with a dense motor block resulting in reduced mobility, decreased pelvic tone, and loss of the bearingdown sensations usually experienced in the second stage of labour? ${ }^{7}$.

Women with epidural also have been described to experience more hypotension, motor blockade, fever, and urinary retention as demonstrated with overwhelming and good quality evidence ${ }^{8,9}$. A relationship has not been found between epidural analgesia use and an increase in neonatal morbidity, usually expressed using low Apgar scores and $\mathrm{pH}$ values of umbilical artery ${ }^{8}$. The aims from this research study are; to show how many Palestinian women use epidural analgesia including the frequency of using it, the reasons why they don't use it, determine the adverse effects from using it, is there is any affects in fetes when epidural analgesia used and if the mother willing to use it again or/ and advise any women to use it.

\section{METHODS}

A cross-sectional study was conducted using an online questionnaire. The study included females (age $<20->40$ years old) from all governorates in Palestine. The survey was designed to measure the knowledge awareness and attitude of Palestinian women toward epidural anesthesia during labor. A total of $\mathbf{2 6 8 5}$ females participated in the study. 1515 women only completed the questionnaire and answered all the questions. Thus, the valid percentage was calculated in the analysis. SPSS version 22 was used to analyze the data collected.

\section{RESULTS}

About 893 women (33\%) who participated in the research study didn't use the epidural analgesia and 1792 (67\%) women used it, out of 2685 women completed the questionnaire. The research study included Palestinian women in different Governorates in Palestine. $43.2 \%$ (800) of women who participated in this research study mentioned that the epidural injection is painless, $29.3 \%$ (543) said that it is painful and others filled it may be painful. In women used epidural injection, the expending of uterus was $1-2 \mathrm{~cm}$ in 355 women (20.5\%), 2-3 cm in 325 women (18.7\%), 3-4 cm in 482 women ( $27.8 \%), 4-5 \mathrm{~cm}$ in 355 women $(20.5 \%)$ and more than $5 \mathrm{~cm}$ in 218 women $(12.6 \%)$. The percentage of birth pain which anesthetized by epidural analgesia; 621 women (35\%) mentioned that the epidural injection anesthetized about $80-100 \%, 24.5 \%$ (434) is $60-80 \%, 13 \%(230)$ is $40-60 \%, 9.4(166)$ is 20 $40 \%$ and $18.2 \%$ (322) is $0-20 \%$. While 795 women (45.9\%) didn't have any difficulty pushing the fetus during delivery but $38.2 \%$ has a difficult push, and $15.9 \%$ said maybe they have. The most signs and symptoms mentioned are headache, backache, nausea, allergy at the site of injection, high body temperature, high blood sugar which a risk factor of diabetes, hypotension or hypertension in others, vomiting, tremor, itching, pain, and numbness in one or both legs, feeling cold, and absents of senses in the lower part for 12 hours after birth. Other results analysis such as; the frequency of uses epidural analgesia, the effects of child, and in which birth number they used it is included. The following tables and figures summarized the results of all the research study:

Table 1: Distribution of participated women according to their governorate

\begin{tabular}{|l|l|l|l|l|}
\hline Governorate & Frequency & \% & Valid \% & Cumulative Percent \\
\hline Jericho & 40 & 1.5 & 1.5 & 1.5 \\
\hline Hebron & 730 & 27.2 & 27.2 & 28.7 \\
\hline Jerusalem & 546 & 20.3 & 20.3 & 49.0 \\
\hline Bethlehem & 165 & 6.1 & 6.1 & 55.2 \\
\hline Jenin & 176 & 6.6 & 6.6 & 61.7 \\
\hline Ramallah & 356 & 13.3 & 13.3 & 75.0 \\
\hline Tulkarm & 138 & 5.1 & 5.1 & 80.1 \\
\hline Gaza & 139 & 5.2 & 5.2 & 85.3 \\
\hline Qalqila & 44 & 1.6 & 1.6 & 86.9 \\
\hline Nablus & 351 & 13.1 & 13.1 & 100.0 \\
\hline Total & 2685 & 100.0 & 100.0 & \\
\hline
\end{tabular}




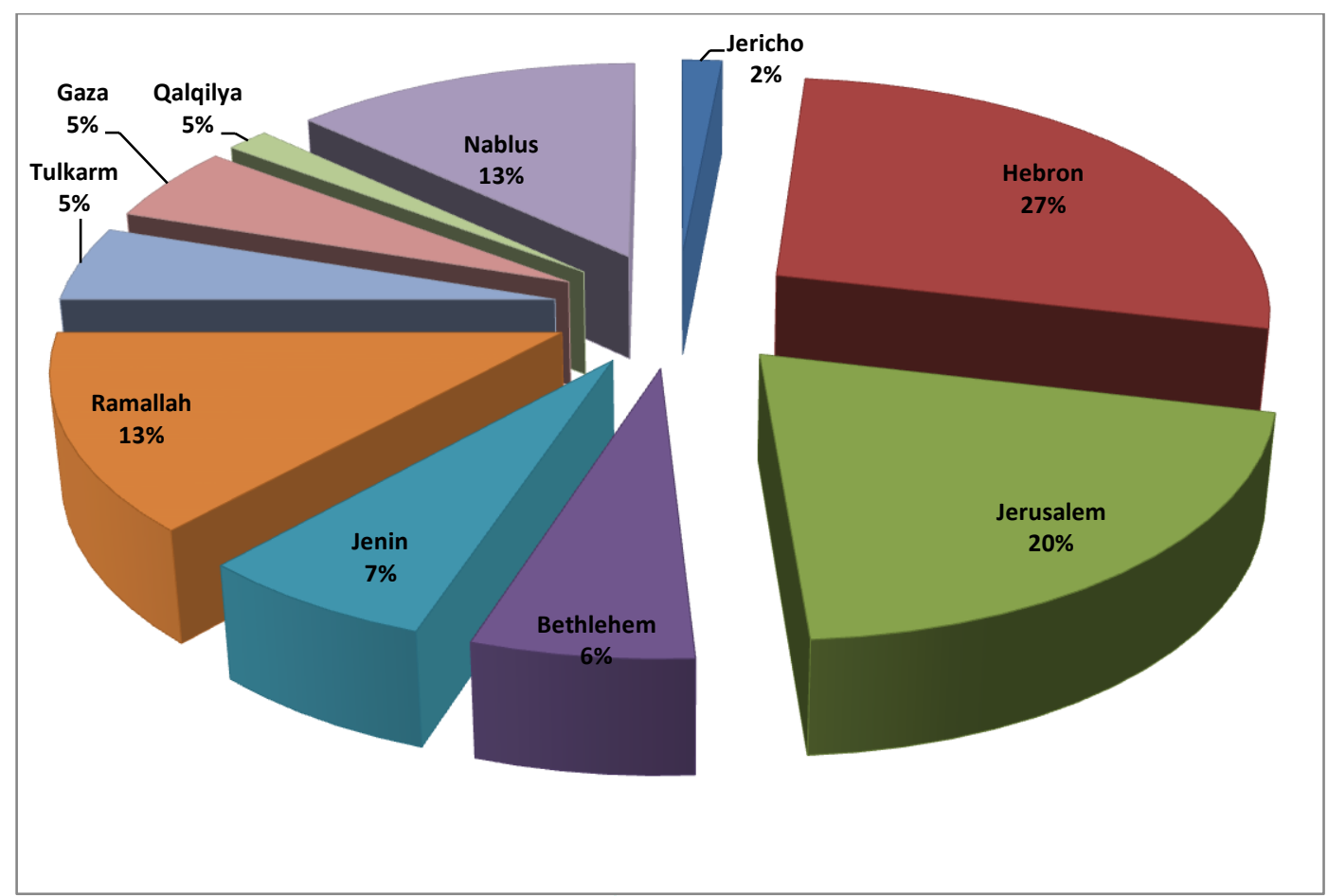

Figure 1: Distribution of participated women according to their governorate

Table 2: The age of the participated women

\begin{tabular}{|l|l|l|l|l|}
\hline Age & Frequency & $\mathbf{\%}$ & Valid \% & Cumulative Percent \\
\hline$<\mathbf{2 0}$ & 138 & 5.1 & 5.1 & 5.1 \\
\hline$>\mathbf{4 0}$ & 16 & 0.6 & 0.6 & 5.7 \\
\hline $\mathbf{2 0 - 2 5}$ & 994 & 37.0 & 37.0 & 42.8 \\
\hline $\mathbf{2 5 - 3 0}$ & 1080 & 40.2 & 40.2 & 83.0 \\
\hline $\mathbf{3 0 - 3 5}$ & 361 & 13.4 & 13.4 & 96.4 \\
\hline $\mathbf{3 5 - 4 0}$ & 96 & 3.6 & 3.6 & 100.0 \\
\hline Total & 2685 & 100.0 & 100.0 & \\
\hline
\end{tabular}

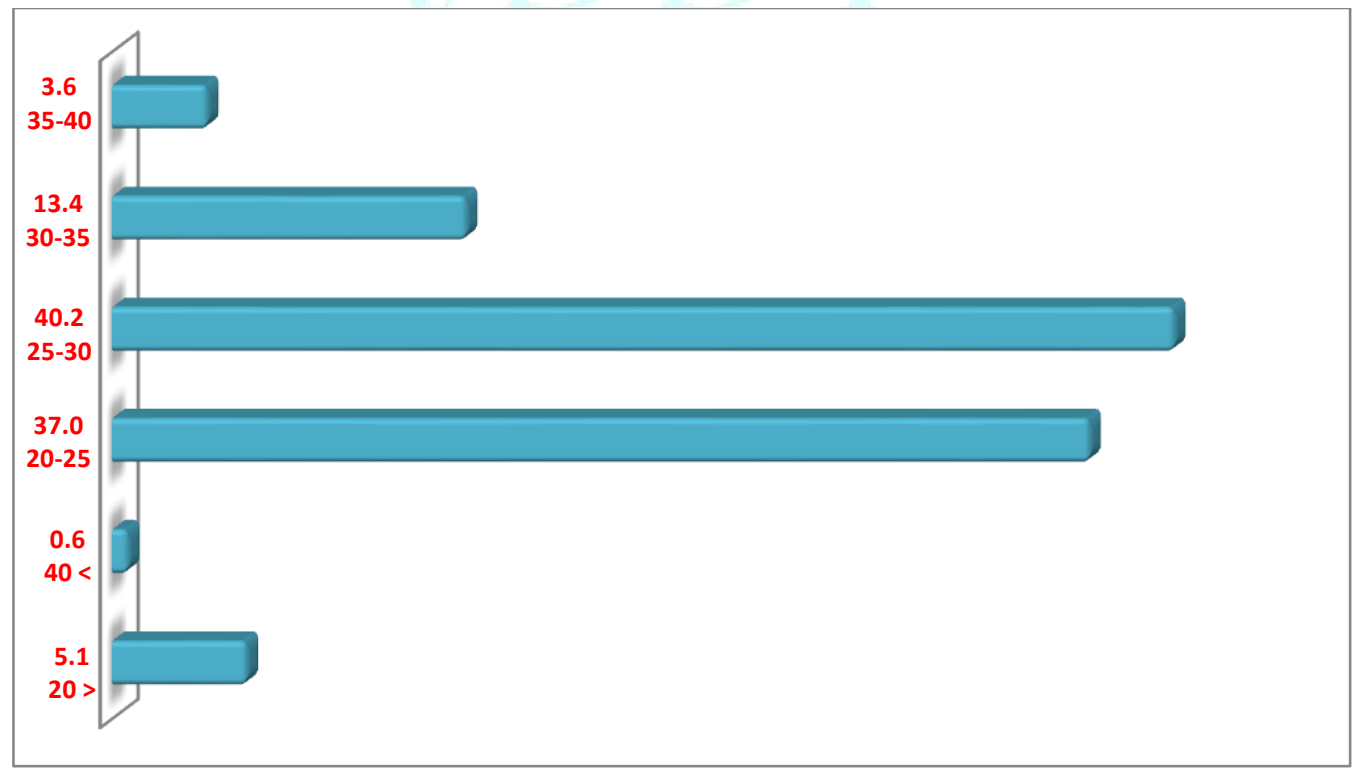

Figure 2: The Age of the Participated Women 
Table 3: The duration of marriage of participated women

\begin{tabular}{|l|l|l|l|l|}
\hline How long you have been married? & Frequency & $\mathbf{\%}$ & Valid \% & Cumulative Percent \\
\hline $\mathbf{> 1 0} \mathbf{y}$ & 291 & 10.8 & 10.8 & 10.8 \\
\hline $\mathbf{1 - 2} \mathbf{y}$ & 786 & 29.3 & 29.3 & 40.1 \\
\hline $\mathbf{2 - 4} \mathbf{y}$ & 733 & 27.3 & 27.3 & 67.4 \\
\hline $\mathbf{4 - 6} \mathbf{y}$ & 432 & 16.1 & 16.1 & 83.5 \\
\hline $\mathbf{6 - 8} \mathbf{y}$ & 245 & 9.1 & 9.1 & 92.6 \\
\hline $\mathbf{8 - 1 0} \mathbf{y}$ & 198 & 7.4 & 7.4 & 100.0 \\
\hline Total & 2685 & 100.0 & 100.0 & 10.8 \\
\hline
\end{tabular}

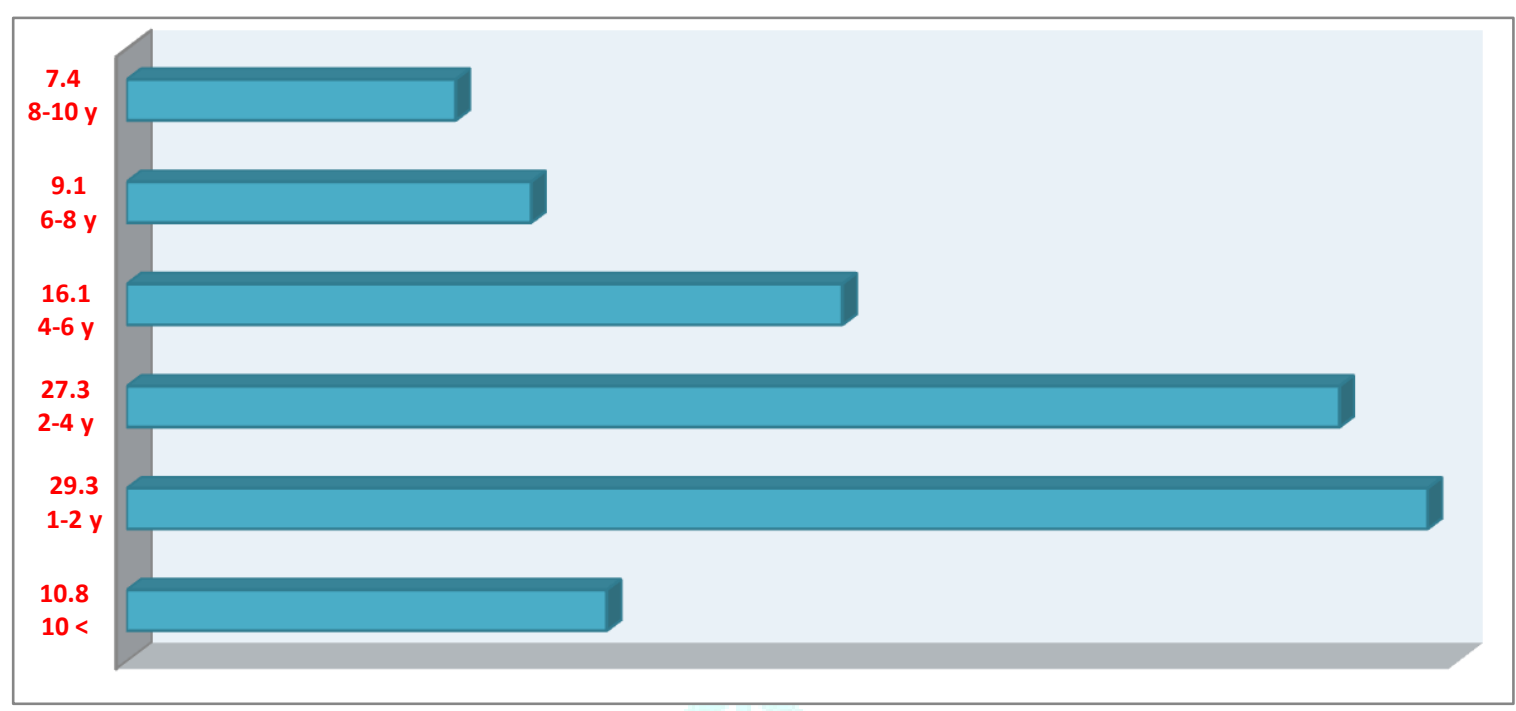

Figure 3: The duration of marriage of participated women

Table 4: The use of epidural analgesia at labor

\begin{tabular}{|l|l|l|l|l|}
\hline $\begin{array}{l}\text { Have you ever used epidural analgesia } \\
\text { at labor? }\end{array}$ & Frequency & \% & Valid \% & $\begin{array}{c}\text { Cumulative } \\
\text { Percent }\end{array}$ \\
\hline No & 893 & 33.3 & 33.3 & 33.3 \\
\hline Yes & 1792 & 66.7 & 66.7 & 100.0 \\
\hline Total & 2685 & 100.0 & 100.0 & \\
\hline
\end{tabular}

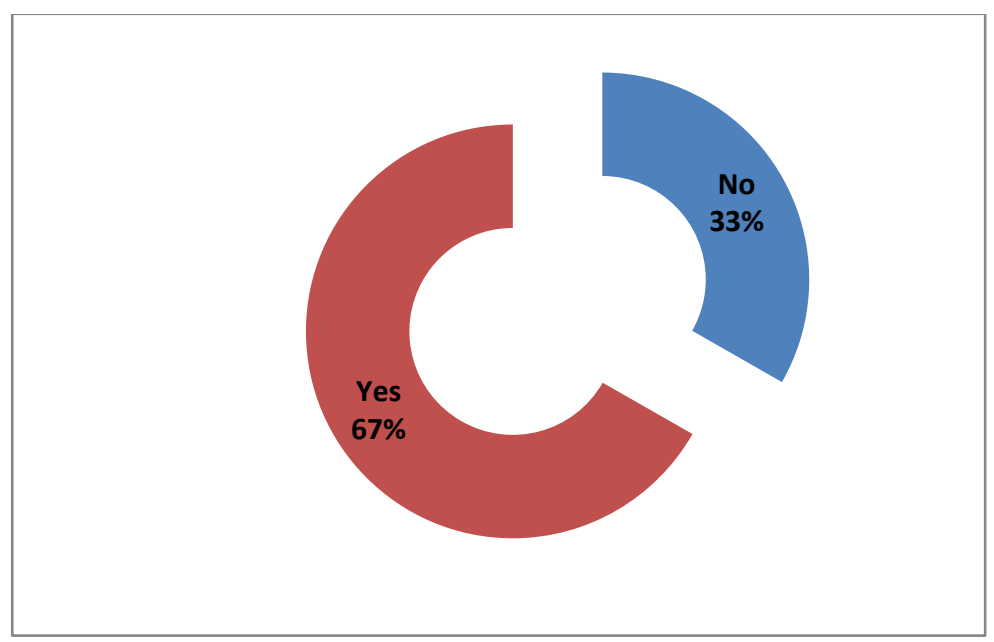

Figure 4: The use of epidural analgesia at labor 
Table 5: The reason for not using epidural analgesia at labor

\begin{tabular}{|c|c|c|c|c|}
\hline Cause & Frequency & $\%$ & $\begin{array}{c}\text { Valid } \\
\%\end{array}$ & $\begin{array}{c}\text { Cumulative } \\
\text { Percent }\end{array}$ \\
\hline $\begin{array}{l}\text { The idea in itself causes me to panic, although I know it is useful and not } \\
\text { harmful. Besides, I had an accident and a fracture of the spine; this } \\
\text { discouraged me not to use it. }\end{array}$ & 1 & 0.056 & 0.113 & 0.113 \\
\hline Wanted to experience the natural birth & 10 & 0.556 & 1.13 & 1.243 \\
\hline Fear of the side effects & 380 & 21.12 & 42.89 & 44.133 \\
\hline Wanted to experience a normal birth without other factors & 2 & 0.111 & 0.226 & 44.359 \\
\hline $\begin{array}{l}\text { During labor, I missed the stage of administration, where the expansion was } \\
\text { more than } 5 \mathrm{~cm}\end{array}$ & 6 & 0.334 & 0.677 & 45.036 \\
\hline $\begin{array}{l}\text { Fear of being given in the back, side effects, and in my second pregnancy, I } \\
\text { used CLEXANE® Injection (Enoxaparin). }\end{array}$ & 1 & 0.056 & 0.113 & 45.149 \\
\hline I felt that I did not need it, and my birth was facilitated well & 14 & 0.778 & 1.58 & 46.729 \\
\hline I wanted the birth to proceed as normal, without any intervention & 1 & 0.056 & 0.113 & 46.842 \\
\hline I knew it and I have faith that everything in the hand of God during birth & 1 & 0.056 & 0.113 & 46.955 \\
\hline The side effects, fear of the injection, and the high cost & 3 & 0.167 & 0.339 & 47.294 \\
\hline I didn't need it as the expansion occurred rapidly & 10 & 0.556 & 1.13 & 48.424 \\
\hline My birth was easy and the pain was tolerable & 2 & 0.111 & 0.226 & 48.65 \\
\hline The fear of the injection because given in the back & 236 & 13.12 & 26.64 & 75.29 \\
\hline $\begin{array}{l}\text { The side effects and fear of the injection because given in the back; as it is a } \\
\text { sensitive area that any mistake leads to serious illnesses. }\end{array}$ & 3 & 0.167 & 0.339 & 75.629 \\
\hline The desire to feel every moment of childbirth, even if it is painful & 1 & 0.056 & 0.113 & 75.742 \\
\hline The Physician didn't recommend it and he said don't need it either. & 1 & 0.056 & 0.113 & 75.855 \\
\hline The hospital did not offer to give me the injection & 3 & 0.167 & 0.339 & 76.194 \\
\hline Cesarean delivery (either used spinal or complete anesthesia) & 41 & 2.28 & 4.628 & 80.822 \\
\hline Childbirth was by cesarean due to preeclampsia & 1 & 0.056 & 0.113 & 80.935 \\
\hline The birth was in Government Hospital, and the injection is not available & 12 & 0.667 & 1.35 & 82.285 \\
\hline $\begin{array}{l}\text { The birth was an emergency due to the detachment of the placenta and was } \\
\text { done under general anesthesia }\end{array}$ & 1 & 0.056 & 0.113 & 82.398 \\
\hline First birth & 3 & 0.167 & 0.339 & 82.737 \\
\hline $\begin{array}{l}\text { They give me CLEXANE® for blood clotting; therefore, it is forbidden to take } \\
\text { the injection. }\end{array}$ & 1 & 0.056 & 0.113 & 82.85 \\
\hline $\begin{array}{l}\text { In the first birth, I did not know about it, and in the second one when I asked } \\
\text { for it the expansion was more than } 5 \mathrm{~cm} \text {; they said you don't need it, and the } \\
\text { birth was smooth with tolerable pain }\end{array}$ & 1 & 0.056 & 0.113 & 82.963 \\
\hline $\begin{array}{l}\text { The birth was in a hospital where there no injections and delivered by } \\
\text { cesarean }\end{array}$ & 1 & 0.056 & 0.113 & 83.076 \\
\hline Premature birth & 1 & 0.056 & 0.113 & 83.189 \\
\hline Due to its cost & 32 & 1.78 & 3.612 & 86.801 \\
\hline Due to the presence of a slipped lumbar spine & 1 & 0.056 & 0.113 & 86.9614 \\
\hline According to the nurse's, I didn't need it even though I wanted to take it & 1 & 0.056 & 0.113 & 87.027 \\
\hline I have not given birth yet & 8 & 0.445 & 0.903 & 87.93 \\
\hline Distrust of physicians and is given in the back & 1 & 0.056 & 0.113 & 88.043 \\
\hline Lack of knowledge about it & 91 & 5.058 & 10.27 & 98.313 \\
\hline I don't want to use it & 1 & 0.056 & 0.113 & 98.426 \\
\hline Unnecessary (especially with the painkillers provided during labor, and some & 2 & 0.111 & 0.226 & 98.652 \\
\hline
\end{tabular}




\begin{tabular}{|c|c|c|c|c|}
\hline medical advice and exercise) & & & & \\
\hline They did not tell us about it & 1 & 0.056 & 0.113 & 98.765 \\
\hline $\begin{array}{l}\text { Low platelets and no clotting and fear of bleeding, so the physician did not } \\
\text { recommend to use }\end{array}$ & 2 & 0.111 & 0.226 & 98.991 \\
\hline $\begin{array}{l}\text { I was pregnant with twins and the physician did not recommend to use it for } \\
\text { fear that I might not respond to the pushing }\end{array}$ & 1 & 0.056 & 0.113 & 99.104 \\
\hline The cervical condition did not allow to use it & 1 & 0.056 & 0.113 & 99.217 \\
\hline It was not familiar when I gave birth & 1 & 0.056 & 0.113 & 99.33 \\
\hline It didn't cross my mind & 1 & 0.056 & 0.113 & 99.443 \\
\hline The unavailable of Anesthetist when I gave birth & 1 & 0.056 & 0.113 & 99.556 \\
\hline Physician prevented giving it due to the slowed heartbeat of the fetus & 2 & 0.111 & 0.226 & 99.782 \\
\hline No reason & 2 & 0.111 & 0.226 & 100 \\
\hline Total & 886* & 49.25 & 100 & \\
\hline Missing (99) & 1799 & & & \\
\hline Total & 2685 & & & \\
\hline
\end{tabular}

*7 women did not give the cause of using the injection; they are not included in the calculations

Table 6: The reason or the person who advises using the epidural analgesia at labor

\begin{tabular}{|c|c|c|c|c|}
\hline Who advises you to use epidural analgesia? & Frequency & $\%$ & $\begin{array}{l}\text { Valid } \\
\%\end{array}$ & $\begin{array}{l}\text { Cumulative } \\
\text { Percent }\end{array}$ \\
\hline I am a doctor, I know it & 5 & 0.186 & 0.281 & 0.281 \\
\hline I wanted to be awake when the fetus came out & 3 & 0.112 & 0.169 & 0.45 \\
\hline I'm midwife or nurse & 8 & 0.298 & 0.450 & 0.9 \\
\hline Labor pain & 18 & 0.670 & 1.01 & 1.91 \\
\hline They gave me the injection without asking me & 2 & 0.074 & 0.112 & 2.022 \\
\hline Because I had high blood pressure and preeclampsia & 2 & 0.074 & 0.112 & 2.134 \\
\hline It was required to use it in my case & 5 & 0.186 & 0.281 & 2.415 \\
\hline Relatives or friends & 583 & 21.71 & 32.77 & 35.185 \\
\hline My mother & 5 & 0.186 & 0.281 & 35.466 \\
\hline Physician & 960 & 35.75 & 53.96 & 89.426 \\
\hline Nurse or midwife & 5 & 0.186 & 0.281 & 89.707 \\
\hline Internet or Facebook groups or Social Media & 23 & 0.857 & 1.29 & 90.997 \\
\hline The fear of birth & 1 & 0.037 & 0.056 & 91.053 \\
\hline Caesarean delivery & 29 & 1.080 & 1.63 & 92.683 \\
\hline My Husband & 5 & 0.186 & 0.281 & 92.964 \\
\hline I chose that (no one advised me, it was my decision) & 37 & 1.378 & 2.08 & 95.044 \\
\hline I work in the obstetrics department & 1 & 0.037 & 0.056 & 95.1 \\
\hline Previous experience & 81 & 3.017 & 4.55 & 99.65 \\
\hline In order not to use general anesthesia (Less risk than full anesthesia) & 3 & 0.112 & 0.169 & 99.819 \\
\hline I was not fasting & 3 & 0.112 & 0.169 & 100 \\
\hline Total & $1779^{*}$ & 66.25 & 100 & \\
\hline Missing $\quad 99$ & 906 & & & \\
\hline Total & 2685 & & & \\
\hline
\end{tabular}

*13 women did not answer this question; they are not included in the calculations 
Table 7: In which birth and/or frequency of using the epidural analgesia

\begin{tabular}{|c|c|c|c|c|}
\hline $\begin{array}{l}\text { In which birth number did you } \\
\text { use epidural analgesia? }\end{array}$ & Frequency & $\%$ & Valid \% & $\begin{array}{c}\text { Cumulative } \\
\text { Percent }\end{array}$ \\
\hline First & 1165 & 43.39 & 63.87 & 63.87 \\
\hline Second & 189 & 7.04 & 10.36 & 74.23 \\
\hline Third & 113 & 4.21 & 6.195 & 80.425 \\
\hline Fourth & 14 & 0.521 & 0.768 & 81.193 \\
\hline Fifth & 5 & 0.186 & 0.274 & 81.464 \\
\hline Sixth & 3 & 0.112 & 0.164 & 81.628 \\
\hline Seventh & 1 & 0.037 & 0.055 & 81.683 \\
\hline More than once & 312 & 11.62 & 17.11 & 98.79 \\
\hline Used in operation of varicose veins & 1 & 0.037 & 0.055 & 98.848 \\
\hline In the last pregnancy & 1 & 0.037 & 0.055 & 98.903 \\
\hline I did not used it & 20 & 0.745 & 1.096 & 100 \\
\hline Total & 1824* & 67.93 & 100 & \\
\hline Missing 99 & 861 & & & \\
\hline Total & 2685 & & & \\
\hline
\end{tabular}

*32 women did not use the injection but they answered the question, they are included in the calculations

Table 8: Frequency of using the epidural analgesia

\begin{tabular}{|l|l|l|l|l|}
\hline $\begin{array}{l}\text { How many times did you use } \\
\text { epidural analgesia? }\end{array}$ & Frequency & $\mathbf{\%}$ & Valid \% & $\begin{array}{l}\text { Cumulative } \\
\text { Percent }\end{array}$ \\
\hline $3<$ & 22 & .8 & 1.2 & 1.2 \\
\hline 3 & 74 & 2.8 & 4.1 & 5.3 \\
\hline 1 & 1424 & 53.0 & 78.4 & 83.7 \\
\hline 2 & 297 & 11.1 & 16.3 & 100.0 \\
\hline Total & 1817 & 67.7 & 100.0 & \\
\hline Missing (99) & 868 & 32.3 & & \\
\hline Total & 2685 & 100.0 & & \\
\hline
\end{tabular}

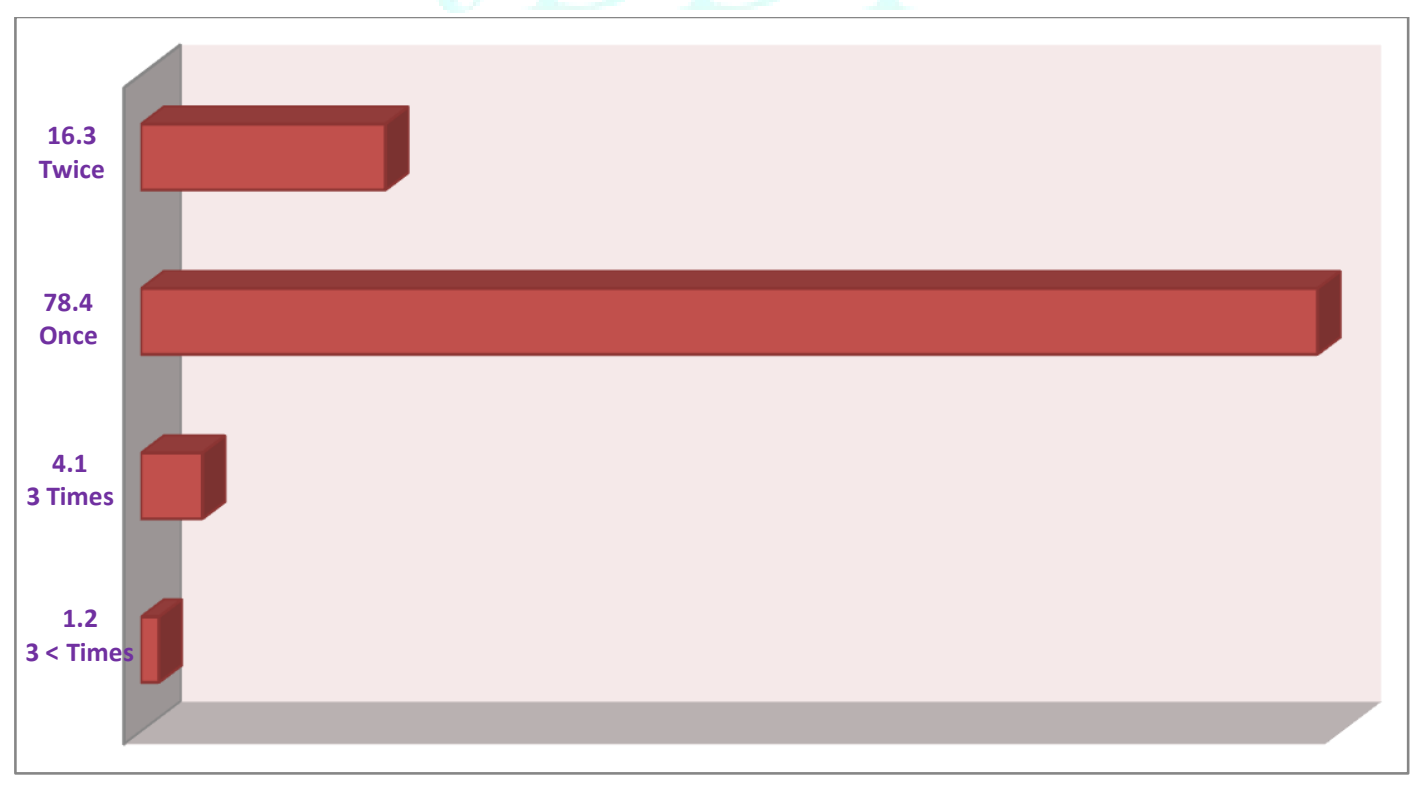

Figure 5: Frequency of using the epidural analgesia 
Table 8: Knowledge about the side effects of epidural analgesia

\begin{tabular}{|l|l|l|l|l|}
\hline $\begin{array}{l}\text { Did you have previous knowledge about the } \\
\text { side effects of epidural analgesia? }\end{array}$ & Frequency & $\mathbf{\%}$ & $\begin{array}{c}\text { Valid } \\
\%\end{array}$ & $\begin{array}{c}\text { Cumulative } \\
\text { Percent }\end{array}$ \\
\hline No & 619 & 23.1 & 29.6 & 29.6 \\
\hline Yes & 1475 & 54.9 & 70.4 & 100.0 \\
\hline Total & 2094 & 78.0 & 100.0 & \\
\hline Missing (99) & 591 & 22.0 & & \\
\hline Total & 2685 & 100.0 & & \\
\hline
\end{tabular}

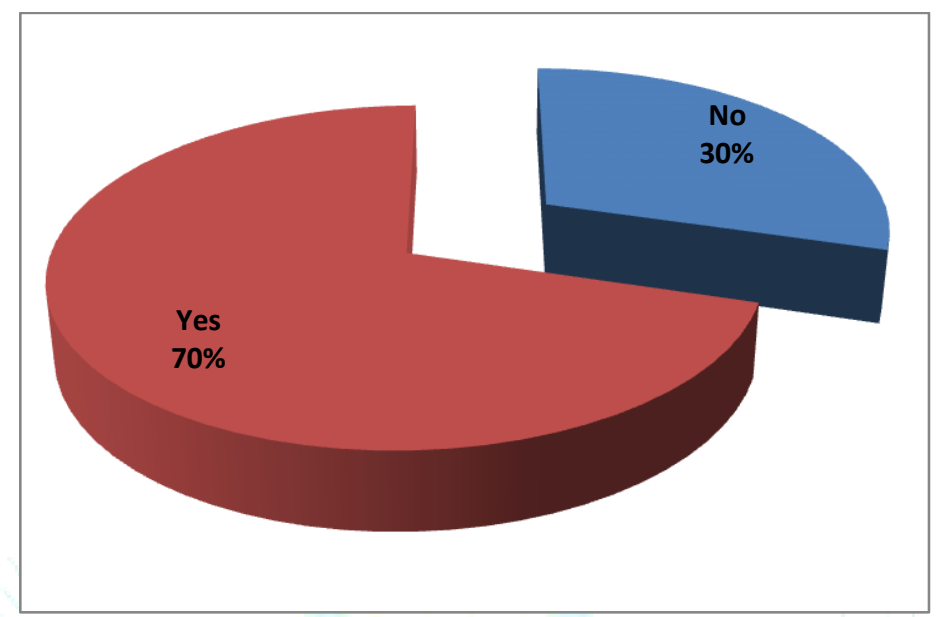

Figure 6: knowledge about the side effects of epidural analgesia

Table 9: The responsibility of the negative effects of epidural analgesia

\begin{tabular}{|l|r|l|l|l|}
\hline $\begin{array}{l}\text { Did you sign a paper that includes your } \\
\text { responsibility if negative effects occur? }\end{array}$ & Frequency & $\mathbf{\%}$ & $\begin{array}{l}\text { Valid } \\
\mathbf{\%}\end{array}$ & $\begin{array}{l}\text { Cumulative } \\
\text { Percent }\end{array}$ \\
\hline No & 679 & 25.3 & 36.4 & 36.4 \\
\hline Yes & 1186 & 44.2 & 63.6 & 100.0 \\
\hline Total & 1865 & 69.5 & 100.0 & \\
\hline Missing (99) & 2620 & 30.5 & & \\
\hline Total & & & & \\
\hline
\end{tabular}

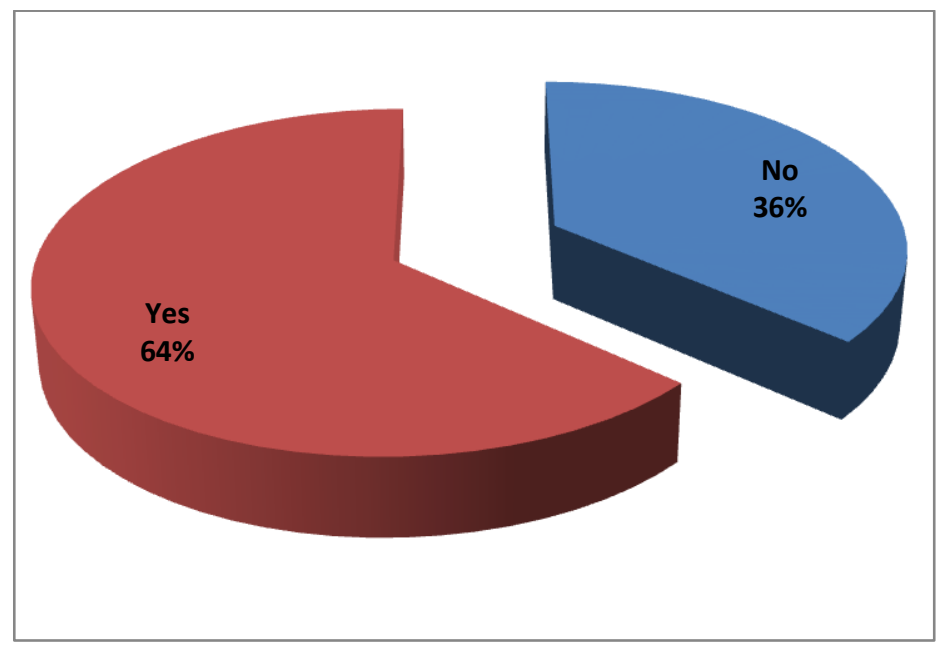

Figure 7: The responsibility of the negative effects of epidural analgesia 
Table 10: Signs and symptoms appear after birth

\begin{tabular}{|c|c|c|c|c|}
\hline After birth, which of these signs and symptoms did you feel? & Frequency & $\%$ & $\begin{array}{l}\text { Valid } \\
\%\end{array}$ & $\begin{array}{l}\text { Cumulative } \\
\text { Percent }\end{array}$ \\
\hline Didn't feel any symptoms & 730 & 27.19 & 39.782 & 39.782 \\
\hline Headache & 97 & 3.613 & 5.29 & 45.072 \\
\hline Backache & 412 & 15.344 & 22.452 & 67.524 \\
\hline Nausea & 45 & 1.676 & 2.452 & 69.976 \\
\hline Allergy at the site of injection & 89 & 3.315 & 4.85 & 74.826 \\
\hline High body temperature (Fever) & 9 & 0.335 & 0.49 & 75.316 \\
\hline Anorexia & 0 & 0.0 & 0.0 & 75.316 \\
\hline High blood sugar that may lead to diabetes & 5 & 0.186 & 0.272 & 75.588 \\
\hline Hypersensitivity & 19 & 0.707 & 1.035 & 76.623 \\
\hline Backache and fever & 17 & 0.633 & 0.926 & 77.549 \\
\hline Anxiety and tension & 35 & 1.30 & 1.91 & 79.46 \\
\hline Foot pain & 3 & 0.112 & 0.163 & 79.622 \\
\hline Hypotension & 3 & 0.112 & 0.163 & 79.785 \\
\hline Backache and Hypersensitivity & 11 & 0.41 & 0.599 & 80.384 \\
\hline Shortness of breath & 2 & 0.074 & 0.109 & 80.493 \\
\hline Back pain, nausea, hypersensitivity & 8 & 0.298 & 0.436 & 80.93 \\
\hline Tingling in the left leg & 1 & 0.037 & 0.054 & 80.983 \\
\hline Headache and Backache & 272 & 10.13 & 14.823 & 95.806 \\
\hline Pain in the shoulders & 3 & 0.112 & 0.163 & 95.969 \\
\hline Hypertension & 3 & 0.112 & 0.163 & 96.132 \\
\hline Fainting & 1 & 0.037 & 0.054 & 96.186 \\
\hline Pain in the site of the injection & 3 & 0.112 & 0.163 & 96.349 \\
\hline Swelling & 2 & 0.074 & 0.109 & 96.458 \\
\hline Back pain and nausea & 17 & 0.633 & 0.926 & 97.384 \\
\hline Back pain, anxiety, and tension & 28 & 1.043 & 1.526 & 98.91 \\
\hline Headache and nausea & 20 & 0.745 & 1.09 & 100 \\
\hline Total & $1835^{*}$ & 68.34 & 100 & \\
\hline Missing 99 & 850 & & & \\
\hline Total & 2685 & & & \\
\hline
\end{tabular}

*43 women did not use the injection but they answered the question, they are included in the calculations

Table 11: Consultation of a physician for signs and symptoms appears after birth

\begin{tabular}{|l|l|l|l|l|}
\hline $\begin{array}{l}\text { If you experience any of the symptoms in } \\
\text { the previous question, did you see a doctor? }\end{array}$ & Frequency & $\mathbf{\%}$ & $\begin{array}{l}\text { Valid } \\
\mathbf{\%}\end{array}$ & $\begin{array}{l}\text { Cumulative } \\
\text { Percent }\end{array}$ \\
\hline No & 884 & 32.9 & 67.9 & 67.9 \\
\hline Yes & 418 & 15.6 & 32.1 & 100.0 \\
\hline Total & 1302 & 48.5 & 100.0 & \\
\hline Missing (99) & 1383 & 51.5 & & \\
\hline Total & 2685 & 100.0 & & \\
\hline
\end{tabular}




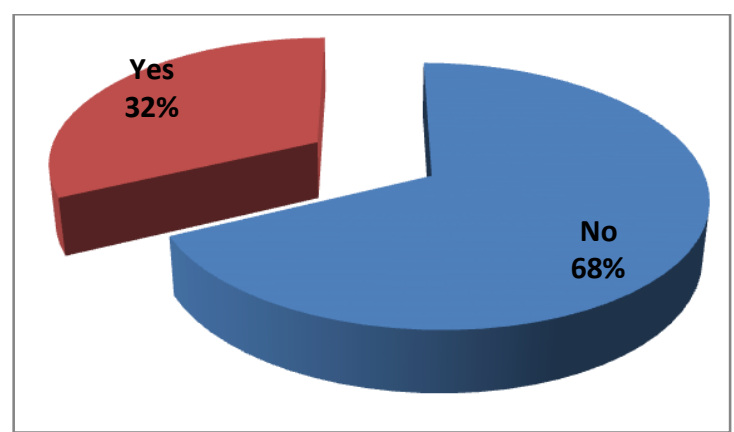

Figure 8: Consultation of a physician for signs and symptoms appears after birth

Table 12: Analysis test before using epidural analgesia

\begin{tabular}{|l|l|l|l|l|}
\hline $\begin{array}{l}\text { Have you had any tests before } \\
\text { epidural analgesia? }\end{array}$ & Frequency & $\%$ & $\begin{array}{l}\text { Valid } \\
\%\end{array}$ & $\begin{array}{l}\text { Cumulative } \\
\text { Percent }\end{array}$ \\
\hline No & 1305 & 48.6 & 71.4 & 71.4 \\
\hline Yes & 524 & 19.5 & 28.6 & 100.0 \\
\hline Total & 1829 & 68.1 & 100.0 & \\
\hline Missing (99) & 856 & 31.9 & & \\
\hline Total & 2685 & 100.0 & & \\
\hline
\end{tabular}

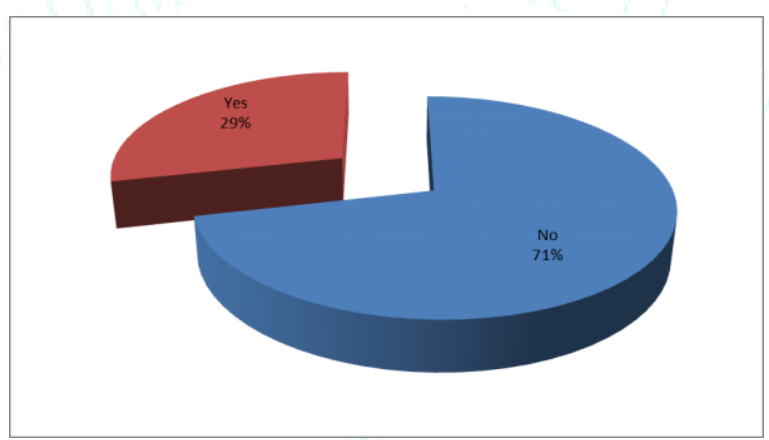

Figure 9: Analysis test before using epidural analgesia

Table 13: Frequency of epidural analgesia if it is painful when injected

\begin{tabular}{|l|l|l|l|l|}
\hline Is epidural analgesia painful when injected? & Frequency & $\mathbf{\%}$ & Valid \% & Cumulative Percent \\
\hline May be & 508 & 18.9 & 27.44 & 27.4 \\
\hline No & 800 & 29.8 & 43.22 & 70.7 \\
\hline Yes & 543 & 20.2 & 29.34 & 100.0 \\
\hline Total & 1851 & 68.9 & 100 & \\
\hline Missing & 834 & 31.1 & & \\
\hline Total & 2685 & 100.0 & & \\
\hline
\end{tabular}

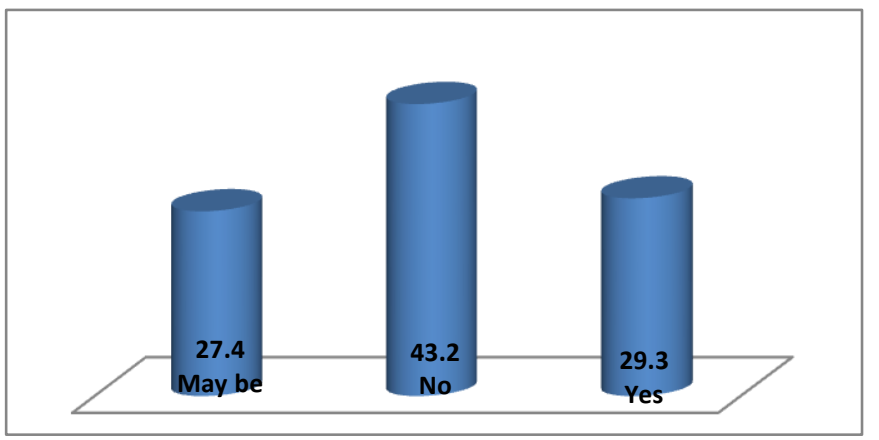

Figure 10: Frequency of epidural analgesia if it is painful when injected 
Table 14: The uterus expanding when epidural analgesia is injected

\begin{tabular}{|l|l|l|l|l|}
\hline $\begin{array}{l}\text { How much your uterus was expanding when } \\
\text { epidural analgesia was injected? }\end{array}$ & Frequency & $\mathbf{\%}$ & Valid \% & $\begin{array}{l}\text { Cumulative } \\
\text { Percent }\end{array}$ \\
\hline $1-2 \mathrm{~cm}$ & 355 & 13.2 & 20.5 & 20.5 \\
\hline $2-3 \mathrm{~cm}$ & 325 & 12.1 & 18.7 & 39.2 \\
\hline $3-4 \mathrm{~cm}$ & 482 & 18.0 & 27.8 & 67.0 \\
\hline $4-5 \mathrm{~cm}$ & 355 & 13.2 & 20.5 & 87.4 \\
\hline More than $5 \mathrm{~cm}$ & 218 & 8.1 & 12.6 & 100.0 \\
\hline Total & 1735 & 64.6 & 100.0 & \\
\hline Missing 99 & 950 & 35.4 & & \\
\hline Total & 2685 & 100 & & \\
\hline
\end{tabular}

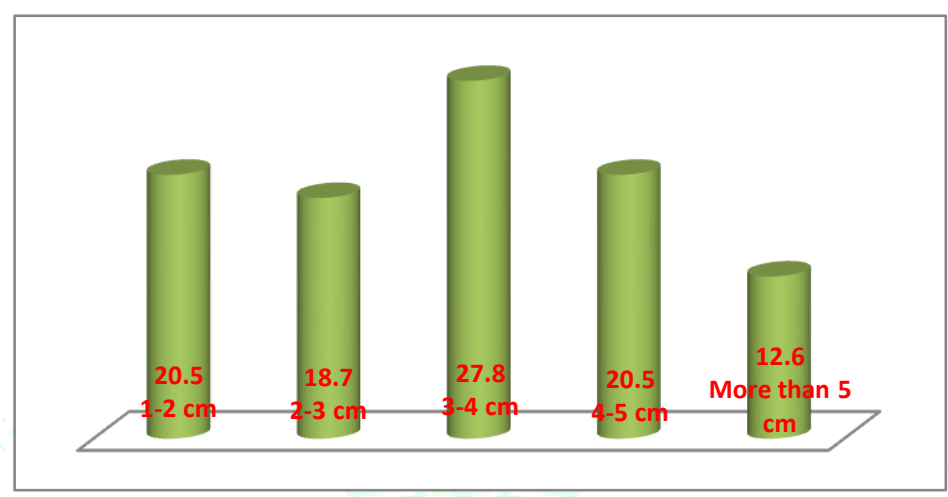

Figure 11: The uterus expanding when epidural analgesia is injected

Table 15: The effect of epidural analgesia on birth pain

\begin{tabular}{|l|l|l|l|l|}
\hline $\begin{array}{l}\text { What percentage of birth pain was } \\
\text { anesthetized by epidural analgesia? }\end{array}$ & Frequency & $\%$ & $\begin{array}{l}\text { Valid } \\
\%\end{array}$ & $\begin{array}{l}\text { Cumulative } \\
\text { Percent }\end{array}$ \\
\hline $0-20 \%$ & 322 & 12.0 & 18.2 & 18.2 \\
\hline $20-40 \%$ & 166 & 6.2 & 9.4 & 27.5 \\
\hline $40-60 \%$ & 230 & 8.6 & 13.0 & 40.5 \\
\hline $60-80 \%$ & 434 & 16.2 & 24.5 & 65.0 \\
\hline $80-100 \%$ & 621 & 23.1 & 35.0 & 100.0 \\
\hline Total $\%$ & 1773 & 66.0 & 100.0 & \\
\hline Missing 99 & 912 & 34.0 & & \\
\hline Total & 2685 & 100.0 & & \\
\hline
\end{tabular}

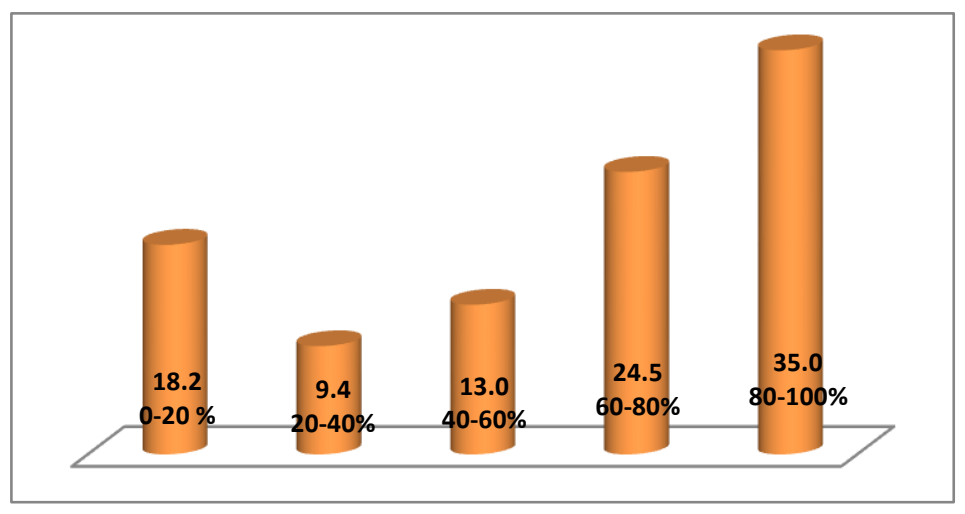

Figure 12: Percentage of epidural analgesia effects on birth pain 
Table 16: Difficulty of pushing the fetus during delivery

\begin{tabular}{|l|l|l|l|l|}
\hline $\begin{array}{l}\text { Have you had difficulty pushing } \\
\text { the fetus during delivery? }\end{array}$ & Frequency & \% & Valid \% & $\begin{array}{c}\text { Cumulative } \\
\text { Percent }\end{array}$ \\
\hline May be & 275 & 10.2 & 15.9 & 15.9 \\
\hline No & 795 & 29.6 & 45.9 & 61.8 \\
\hline Yes & 661 & 24.6 & 38.2 & 100.0 \\
\hline Total & 1731 & 64.5 & 100.0 & \\
\hline Missing 99 & 954 & 35.5 & & \\
\hline Total & 2685 & 100.0 & & \\
\hline
\end{tabular}

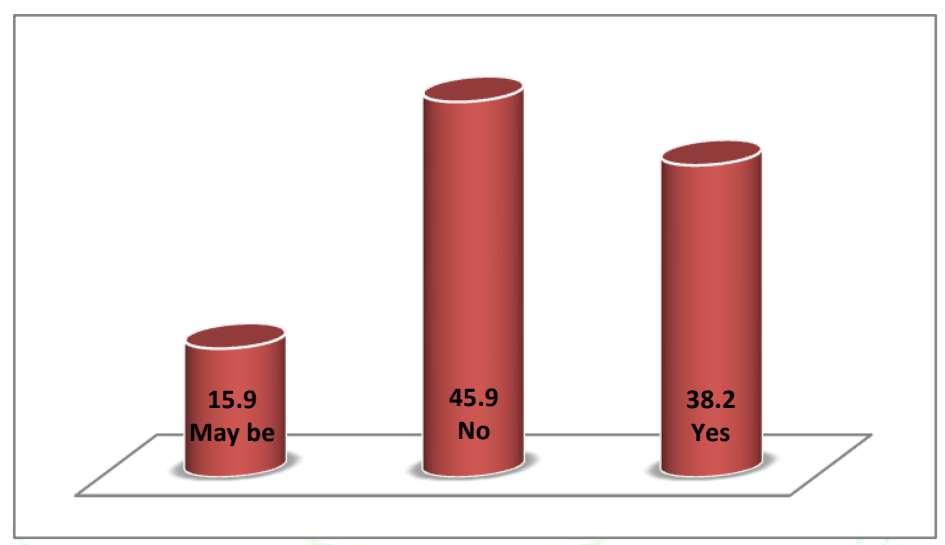

Figure 13: Difficulty of pushing the fetus during delivery

Table 17: Time of return of sensation of the lower body

\begin{tabular}{|l|l|l|l|l|}
\hline $\begin{array}{l}\text { When the sensation return to the lower body and the } \\
\text { effect of anesthesia goes after the epidural analgesia? }\end{array}$ & Frequency & \% & Valid \% & $\begin{array}{l}\text { Cumulative } \\
\text { Percent }\end{array}$ \\
\hline After 0-1 h & 362 & 13.5 & 20.2 & 20.2 \\
\hline After 1-2 h & 449 & 16.7 & 25.1 & 45.4 \\
\hline After. 2-3 h & 384 & 14.3 & 21.5 & 66.8 \\
\hline After More than 3 h & 593 & 22.1 & 33.2 & 100.0 \\
\hline Total 99 & 1788 & 66.6 & 100.0 & \\
\hline Missing & 897 & 33.4 & & \\
\hline Total & 2685 & 100.0 & & \\
\hline
\end{tabular}

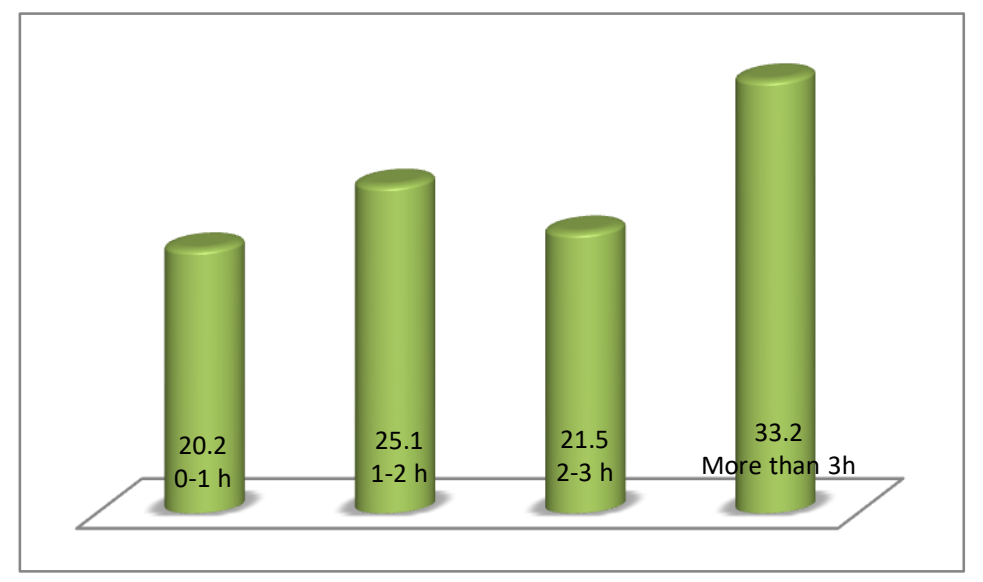

Figure 14: Time of return of sensation of the lower body 
Table 18: The effect of epidural analgesia on the child

\begin{tabular}{|l|l|l|l|l|}
\hline $\begin{array}{l}\text { Did your child been affected by } \\
\text { the epidural analgesia? }\end{array}$ & Frequency & $\mathbf{\%}$ & Valid \% & $\begin{array}{l}\text { Cumulative } \\
\text { Percent }\end{array}$ \\
\hline May be & 95 & 3.5 & 5.2 & 5.2 \\
\hline No & 1657 & 61.7 & 91.2 & 96.5 \\
\hline Yes & 64 & 2.4 & 3.5 & 100.0 \\
\hline Total & 1816 & 67.6 & 100.0 & \\
\hline Missing 99 & 869 & 32.4 & & \\
\hline Total & 2685 & 100.0 & & \\
\hline
\end{tabular}

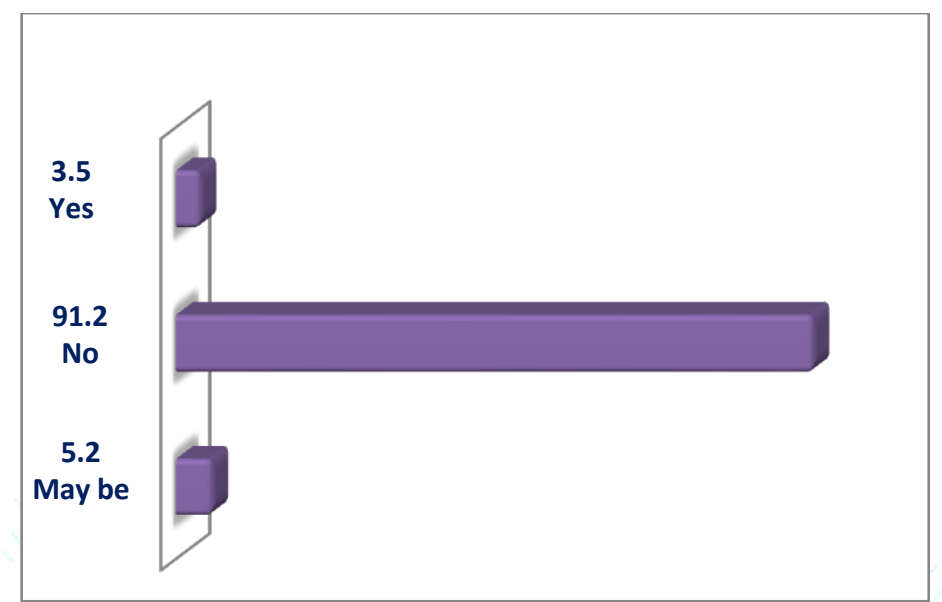

Figure 15: The effect of epidural analgesia on the child

Table 19: Long-term effect of epidural analgesia

\begin{tabular}{|l|l|l|l|l|}
\hline $\begin{array}{l}\text { Have you been affected by the epidural analgesia in } \\
\text { the long-term and symptoms remain for a long time? }\end{array}$ & Frequency & $\mathbf{\%}$ & Valid \% & $\begin{array}{l}\text { Cumulative } \\
\text { Percent }\end{array}$ \\
\hline May be & 262 & 9.8 & 14.4 & 14.4 \\
\hline No & 1139 & 42.4 & 62.5 & 76.9 \\
\hline Yes & 420 & 15.6 & 23.1 & 100.0 \\
\hline Total & 1821 & 67.8 & 100.0 & \\
\hline Missing 99 & 864 & 32.2 & & \\
\hline Total & 2685 & 100.0 & & \\
\hline
\end{tabular}

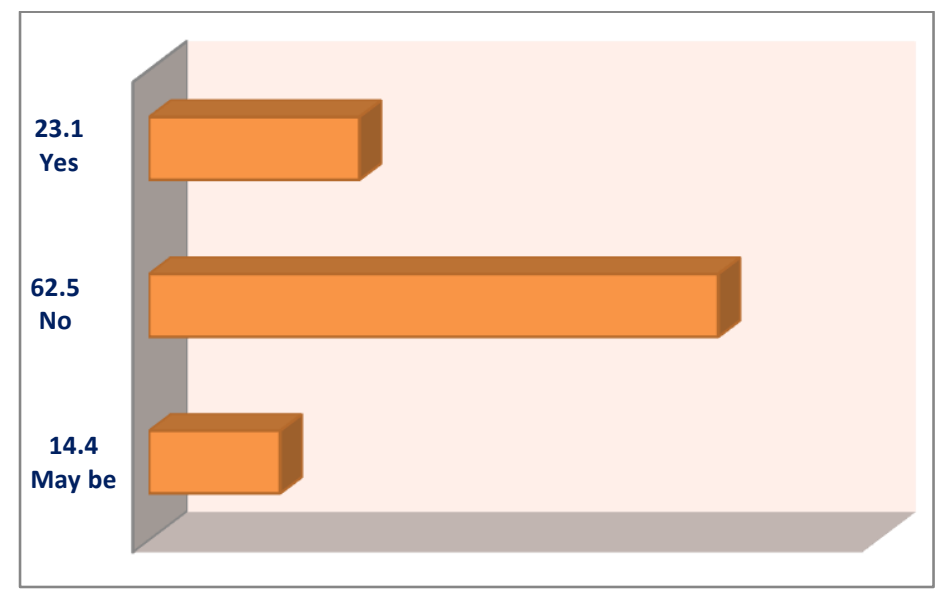

Figure 16: Long-term effect of epidural analgesia 
Table 20: Use the epidural analgesia in the next pregnancy

\begin{tabular}{|l|l|l|l|l|}
\hline $\begin{array}{l}\text { Are you thinking about trying the epidural } \\
\text { analgesia in the next pregnancy? }\end{array}$ & Frequency & $\%$ & Valid \% & $\begin{array}{l}\text { Cumulative } \\
\text { Percent }\end{array}$ \\
\hline May be & 291 & 10.8 & 14.6 & 14.6 \\
\hline No & 489 & 18.2 & 24.5 & 39.0 \\
\hline Yes & 1218 & 45.4 & 61.0 & 100.0 \\
\hline Total & 1998 & 74.4 & 100.0 & \\
\hline Missing 99 & 687 & 25.6 & & \\
\hline Total & 2685 & 100.0 & & \\
\hline
\end{tabular}

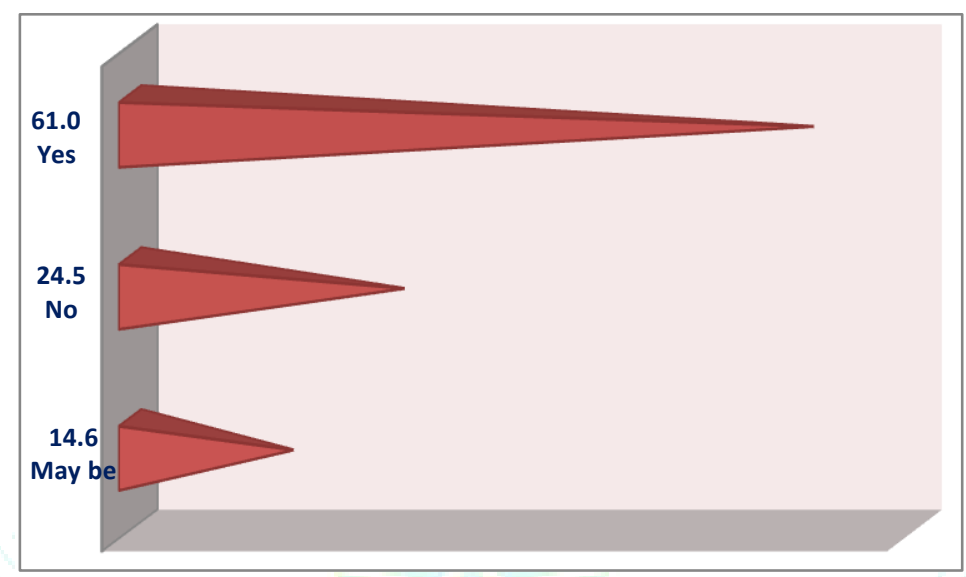

Figure 17: Use the epidural analgesia in the next pregnancy

Table 21: Experience of symptoms by the use of the epidural analgesia more than once

\begin{tabular}{|l|l|l|l|l|}
\hline $\begin{array}{l}\text { If you use the epidural analgesia more than once, do } \\
\text { you experience the same symptoms the first time? }\end{array}$ & Frequency & \% & Valid \% & $\begin{array}{l}\text { Cumulative } \\
\text { Percent }\end{array}$ \\
\hline Fewer symptoms than the first time & 130 & 4.8 & 8.8 & 8.8 \\
\hline More symptoms than the first time & 78 & 2.9 & 5.3 & 14.2 \\
\hline Don't use it more than one time & 1068 & 39.8 & 72.7 & 86.9 \\
\hline The same symptoms the first time & 193 & 7.2 & 13.1 & 100.0 \\
\hline Total & 1469 & 54.7 & 100.0 & \\
\hline Missing & 1216 & 45.3 & & \\
\hline Total & 2685 & 100.0 & & \\
\hline
\end{tabular}

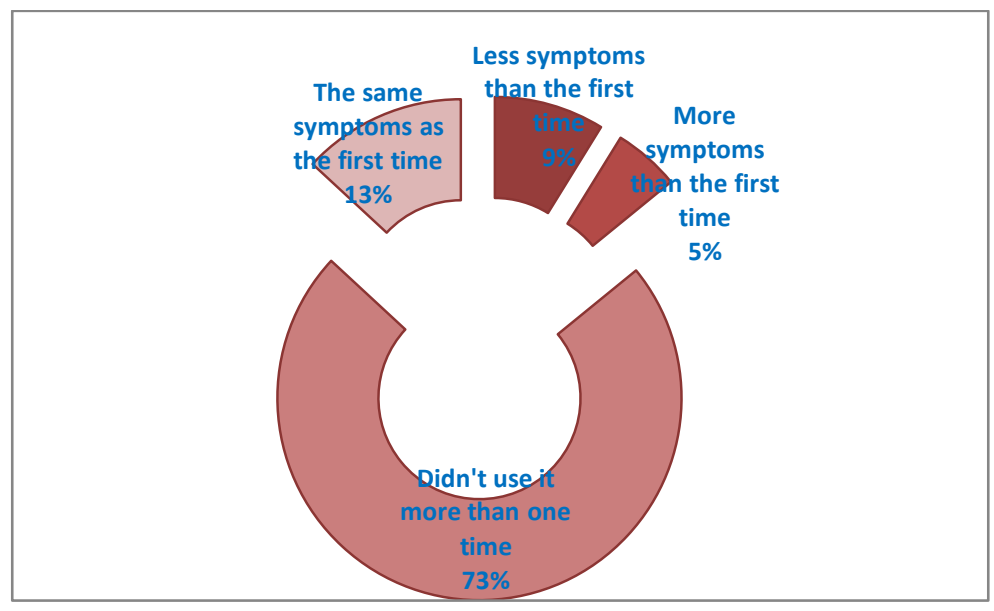

Figure 18: Experience of symptoms by the use of the epidural analgesia more than once 
Table 22: Support using the epidural analgesia in the first pregnancy

\begin{tabular}{|l|l|l|l|l|}
\hline $\begin{array}{l}\text { Do you support using the epidural analgesia } \\
\text { in the first pregnancy? }\end{array}$ & Frequency & $\mathbf{\%}$ & Valid \% & $\begin{array}{l}\text { Cumulative } \\
\text { Percent }\end{array}$ \\
\hline No & 576 & 21.5 & 29.3 & 29.3 \\
\hline Yes & 1393 & 51.9 & 70.7 & 100.0 \\
\hline Total & 1969 & 73.3 & 100.0 & \\
\hline Missing 99 & 716 & 26.7 & & \\
\hline Total & 2685 & 100.0 & & \\
\hline
\end{tabular}

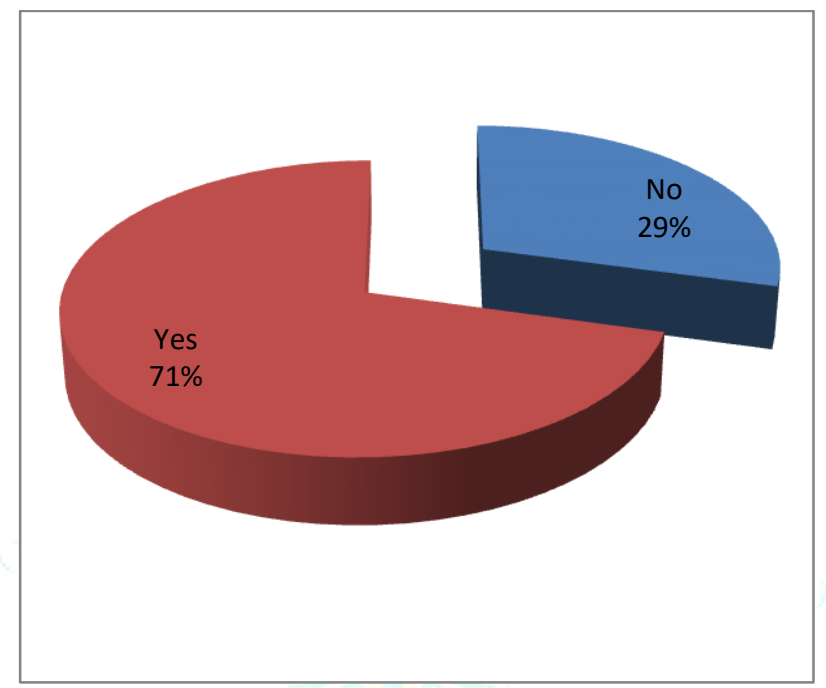

Figure 19: Support using the epidural analgesia in the first pregnancy

Table 23: Advise other women to use the epidural analgesia

\begin{tabular}{|l|l|l|l|l|}
\hline $\begin{array}{l}\text { Do you advise other women to } \\
\text { use the epidural analgesia? }\end{array}$ & Frequency & \% & Valid \% & $\begin{array}{c}\text { Cumulative } \\
\text { Percent }\end{array}$ \\
\hline No & 566 & 21.1 & 28.1 & 28.1 \\
\hline Yes & 1449 & 54.0 & 71.9 & 100.0 \\
\hline Total & 2015 & 75.0 & 100.0 & \\
\hline Missing & 670 & 25.0 & & \\
\hline Total & 2685 & 100.0 & & \\
\hline
\end{tabular}

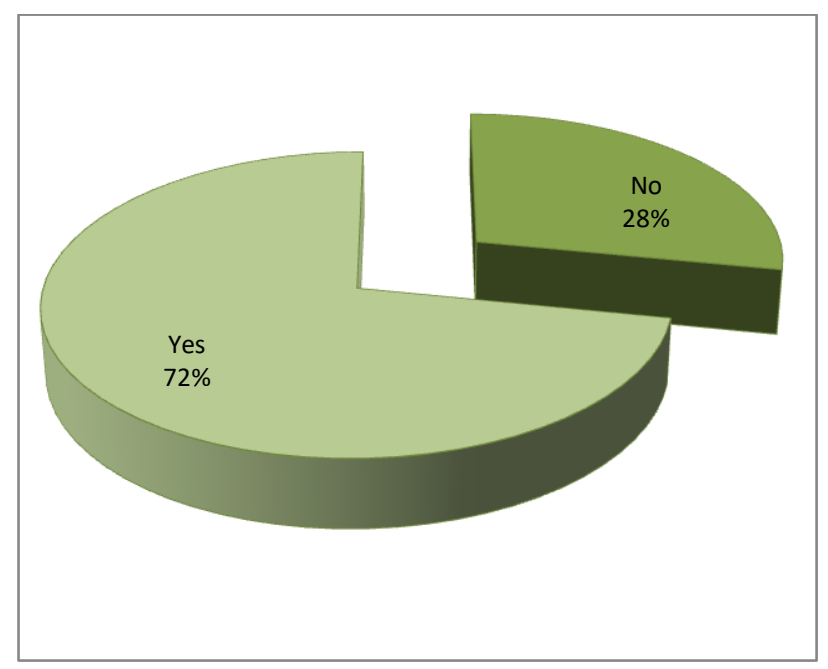

Figure 20: Advise other women to use the epidural analgesia 
Table 24: Spreading and demand for epidural analgesia

\begin{tabular}{|l|l|l|l|l|}
\hline $\begin{array}{l}\text { Do you feel that the epidural analgesia is spreading widely } \\
\text { in the recent period and has a demand? }\end{array}$ & Frequency & $\mathbf{\%}$ & $\begin{array}{l}\text { Valid } \\
\mathbf{\%}\end{array}$ & $\begin{array}{l}\text { Cumulative } \\
\text { Percent }\end{array}$ \\
\hline May be & 232 & 8.6 & 10.9 & 10.9 \\
\hline No & 35 & 1.3 & 1.6 & 12.5 \\
\hline Yes & 1867 & 69.5 & 87.5 & 100.0 \\
\hline Missing & 2134 & 79.5 & 100.0 & \\
\hline Total & 551 & 20.5 & & \\
\hline Total & 2685 & 100.0 & & \\
\hline
\end{tabular}

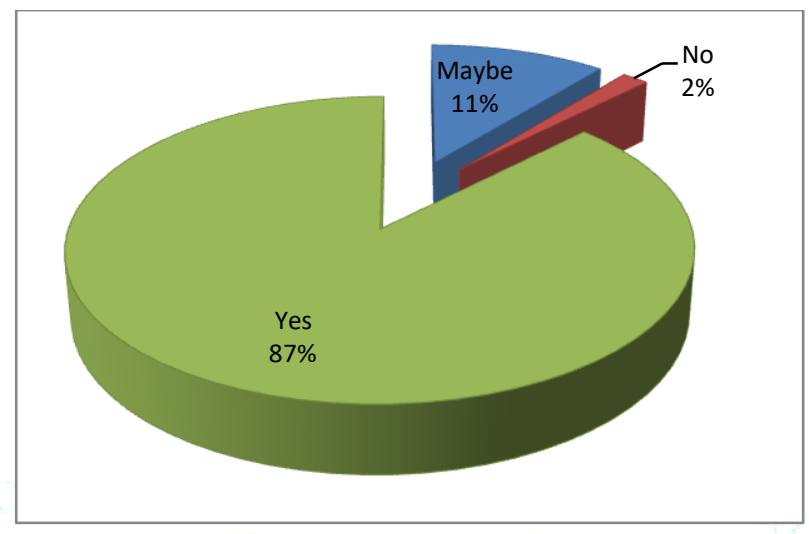

Figure 21: Spreading and demand of epidural analgesia

All the Tables and Figures can be summarized and interpretation as the following: The majority of the participated women were from Hebron Governorate $(\sim 27 \%)$, then Jerusalem ( $20 \%)$, and Ramallah and Nablus Governorates $(\sim 13 \%)$ respectively (Table and Figure 1$)$, this might be because Hebron governorate has the highest population density in Palestine. Most women participated in the study; their age is between $25-30(\sim 40 \%)$ then women aged between 20-25 (37\%) as shown in Table and Figure 2. About 786 women (29\%) completed the questionnaire have been married for 1-2 years, while 733 women their marriage were 2-4 years as shown in Table and Figure 3 . About $43 \%$ of the women (380) in this study didn't use the epidural analgesia because they are fearing from its side effects; which high, while 236 women $(\sim 27 \%)$ didn't use it because they fear of the injection. After all, it is given in the back, 41 women $(\sim 5)$ they did not use it because they delivered their babies by cesarean delivery and either used spinal or complete anesthesia, and only 91 women ( 10\%) didn't use it due to lack of knowledge about it. The cost one of the reasons women didn't use the injection as 32 women due to the cost did not use epidural analgesia and 14 women their birth was facilitated well so they felt that they didn't need it. It is worth mentioning that 10 women only wanted to experience natural birth so they refuse to take it. Other causes were summarized in Table 5.

Table 6 summarized the reason or the person who advise the participated women to use the epidural analgesia at labor; 960 women $(\sim 54 \%)$ were used it as the physicians advised them to do that, 583 women $(\sim 33 \%)$ used according to the advice of their relatives or friends, and 81 women from previous experience they have been used the injection. Besides, nobody advised 37 women to used it; they used it by themselves as it was their own decision, and 23 women used it after searching or know about it from the internet or Facebook groups or social media. Only 18 women take the injection due to the labor pain and 29 women used the epidural analgesia in their cesarean delivery as they believe that it is better and safer than full anesthesia. Other reasons were shown in Table 6 as mentioned.

The majority of women used the epidural analgesia more than one time $(312 ; \sim 17 \%)$ and in first and second birth as 1165 women $(\sim 64 \%)$ used in first birth and 189 women used it in the second one as shown in Table 7 . About $78 \%$ of women (1424) used the injection only one time, this may be their delivery is the first one or due to the cost or other reasons, while $\sim 16 \%$ (297 women) used it twice as shown in Table 7 and Figure 5. Only 619 women $(\sim 30 \%)$ who used it didn't know the side effects of epidural analgesia, while most of the women used the injection have (1475 women; 70\%, Table 8 and Figure 6 ). Most of the participated women used the epidural analgesia (1186 women, $\sim 64 \%$ ) signed a consent form including the responsibility of any negative effects occurs and $\sim 36 \%$ (679 women) of the women didn't sign anything (Table 9 and Figure 7). Nearly 40\% (730) of the women used epidural analgesia didn't feel signs and symptoms appear after birth, while 412 women ( 22\%), it is difficult to conclude if this pain is due to the injection or the birth. Other signs and symptoms women feel both headache and back pain together (272 women; $15 \%$ ) or headache alone ( 97 women, $\sim 5 \%$ ). It is worth to mention that some women who used the epidural analgesia injection (89) suffer from the allergy at the site of injection. Other signs and symptoms occur in women after they used the injection are shown in Table 10. 1383 women out of 1835 women who experienced signs and symptoms after the use of the injection answered the question if they consult a doctor for the signs and symptoms they faced, only 418 women of them $(\sim 32 \%)$ have seen a doctor and 884 women $(\sim 68 \%)$ didn't see any doctor for that (Table 11 and Figure.( 
Regarding any analytical test the women had before using the injection, the majority of them did not have any test (1305 women; $\sim 71 \%)$, while only 524 women $(\sim 29 \%)$ had tested before using the epidural analgesia injection (Table 12 and Figure 9). When we asked the women who used the injection if it is painful when injected, 543 women $(29.34 \%)$ answered, 800 women ( $43.22 \%)$ answered no; it isn't painful, and 508 women $(27.44 \%)$ said it is maybe painful (Table 13 and Figure 10$) .482$ women $(\sim 28 \%)$ were given the epidural analgesia when their uterus expansion is 3-4 $\mathrm{cm}, 355$ women given the injection when their uterus expansion 1-2 cm, and also 355 women when the expansion of their uterus is $4-5 \mathrm{~cm}$, while when the expansion is more than $5 \mathrm{~cm}$; only 218 women are given the injection and when it is $2-3 \mathrm{~cm} 325$ women is also given the injection as shown in Table 14 and Figure 11. When the women asked what is the percentage of the epidural analgesia reduce the pain as shown in Table 15 and Figure 12, 35\% of the women (621) said it reduces the pain by $80-100 \%$, while 434 women said it reduces by $60-80 \%$, and 322 women answered it only reduces the pain by $0-20 \%$ and 230 women mentioned it is $40-60 \%$ affect the pain. The question about the difficulty of pushing the fetus during delivery after taking the injection, 795 women $(\sim 46 \%)$ said that they did not face any difficulty, 661 women said yes $(\sim 38 \%)$, and 275 women $(\sim 16 \%)$ said may be as shown in Table 16 and Figure 13. In 593 women the sensation of the lower body returned after more than 3 hours, in 449 women after 1-2 hours, in 384 women after 23 hours and in 362 it returns after $0-1$ hour as shown in Table 17 and Figure 14.

Table 18 and Figure 15 shows the answered of women; if the epidural analgesia affects their child, majority of women (1657; 91\%) said the injection didn't affect their Childs and 1139 women $(\sim 77 \%)$ said their no long-term effect as well (Table 19 and Figure 16). 1218 women (61\%) are willing to take the epidural analgesia injection in the next pregnancy as shown in Table 20 and Figure 17. When women who used the injection asked; if they use the epidural analgesia more than once, did they experience the same symptoms the first time? 1068 women answered that they didn't use it more than one time, 193 women answered the symptoms are the same as the first time and 130 women mentioned they experienced fewer symptoms than the first time, while 78 women experienced more symptoms than the first time (Table 21 and Figure 18). 1393 women ( 71\%) support using the epidural analgesia in the first pregnancy and 576 women $(\sim 29 \%)$ didn't support (Table 22 and Figure 19). About 72\% of women (1449) willing to advise other women to use the epidural analgesia, while 566 women $(\sim 28 \%)$ not willing to advise other women of using the injection. 1867 women $(\sim 88 \%)$ feel that the epidural analgesia is spreading widely in the recent period and has a demand, while only 35 women said it isn't, and 232 women said it maybe is spreading widely in the recent period and has a demand.

\section{DISCUSSION}

The research study included 2685 Palestinian women, which they have filled the questionnaire online, that women are divided into two groups. The first group was 893 women $(\sim 33 \%)$ who didn't use the epidural analgesia, and the second group is $1792(\sim 67 \%)$ women who used the analgesia during labor.

The research study included Palestinian women from different Governorates in Palestine. The participated women are as the following: $27.0 \%$ of women from Hebron, $20.0 \%$ from Jerusalem, $6 \%$ from Bethlehem, $7.0 \%$ from Jenin, 13.0\% from Ramallah, 5\% from Tulkarm, 5\% from Gaza, 2\% from Qalqilya, 13\% from Nablus and 2\% from Jericho. The age of these women is between 25-30 years (40.2\%), between 20 -25 years (37.0\%), between $30-35$ years $(13.4$ $\%), 3.6 \%$ are between $35-40$ years, $5.1 \%$ is less than 20 years and $0.6 \%$ is more than 40 years old. The period of the marriage of these women filled the questionnaire are $7.4 \%$ 8-10 years, 9.1\% 6-8 years, $16.1 \%$ 4-6 years, $27.3 \% 2-4$ years, $29.31-2$ years, and $10.8 \%$ more than 10 years. To the best of our knowledge, this is the first study about epidural analgesia in Palestinian women.

For different reasons 893 women didn't use the injection, the majority of women $(380, \sim 43 \%)$ didn't use it because they are fearful of the side effects of the epidural analgesia. While 236 women ( $27 \%)$, didn't take it due to their fears as it is given in the back. $\sim 10 \%$ (91 women) have a lack of knowledge about the injection; they didn't know and nobody told them about it, thus they didn't use it. The high cost of the injection also one of the factors why the women didn't use it, as 32 women mentioned due to this reason they even try it. Some women (41) delivered their babies by cesarean and given either spinal or complete anesthesia instead of epidural analgesia. Some women wanted to experience the natural birth or the expansion occurred rapidly so they didn't use or need it. Other women their birth was facilitated well or the injection is not available in the hospital they delivered their babies. It is worth mentioning that the Palestinian Government hospitals do not have the epidural analgesia injection; it is only available in the private hospitals and/or medical centers. All other reasons why women didn't use it are summarized in Table 5.

About $70 \%$ of women that used the epidural analgesia found to know the side effects of Epidural analgesia and 30\% are not. However, $64 \%$ of women who used the epidural analgesia have signed a form of responsibility for any negative effects, and $36 \%$ are not. Most of the women used the Epidural due to the advice from other women or people such as a member of family or friends, physicians, or because they are a member of medical staff (nurses, physicians, .etc.). Some women came to know about epidural analgesia from Facebook groups. Other women are hardly reading or hearing about epidural analgesia and severe pain from labor.

The sign and symptoms in women used epidural analgesia are includes headache, backache, nausea, allergy at the site of injection, high body temperature, high blood sugar which may lead to diabetes, hypotension or hypertension, vomiting, tremor, itching, pain, and numbness in one or two legs, feeling cold, didn't feel in their lower part for 12 hours after birth. It is worth mentioning that these or other symptoms didn't appear in all women but they occur in some of them. Other women didn't feel any symptoms at all. $32 \%$ of women who suffer from various side effects have visited the physician for treatment from these signs and symptoms, while $68 \%$ of women did not visit any physician. Women who experienced the sign and symptoms from Epidural analgesia they mentioned it is not a reason not to use the injection again because they feel it is not too harmful and not a real reason for not using the injection again. However, the sign and symptoms can be classified as mild or moderate symptoms and the effect is not prolonged. Women who used Epidural analgesia 29\% of them did medical tests before the use of the injection, while $71 \%$ of them did not do any medical tests because they believe it is an extremely effective and popular treatment for labor pain.

In Canada, the epidural rate varies between the provinces from $30 \%$ to $69 \% 10$. The use of epidural analgesia in the US has tripled between 1981 and 2001, with 60\% of women using this technique in large hospitals ${ }^{11}$. In our research study, $67 \%$ of women (1792) used Epidural analgesia 
injection. $43.2 \%(800)$ of women who participated in this research study mentioned that the epidural injection is painless, 29.3\% (543) said that it is painful and others filled it may be painful. In women used epidural injection, the expending of uterus was $1-2 \mathrm{~cm}$ in 355 women (20.5\%), 2-3 $\mathrm{cm}$ in 325 women (18.7\%), $3-4 \mathrm{~cm}$ in 482 women $(27.8 \%)$, $4-5 \mathrm{~cm}$ in 355 women (20.5\%) and more than $5 \mathrm{~cm}$ in 218 women $(12.6 \%)$. The percentage of birth pain which anesthetized by epidural analgesia; 621 women (35\%) mentioned that the epidural injection anesthetized about 80 $100 \%, 24.5 \%(434)$ is $60-80 \%, 13 \%$ (230) is $40-60 \%, 9.4$ (166) is $20-40 \%$ and $18.2 \%$ (322) is $0-20 \%$. While 795 women (45.9\%) didn't have any difficulty pushing the fetus during delivery but $38.2 \%$ has a difficult push, and $15.9 \%$ said maybe they have. $20.2 \%$ of the women sensation return to the lower body and the effect of anesthesia abolish after $0-1$ hours, $25.1 \%$ is after $1-2$ hours, 21.5 is after $2-3$ hours, and $33.2 \%$ after more than 3 hours.

The effects of epidural injection in Childs, $91.2 \%$ of women participated in this research study, and used the epidural injection did not affect their Childs, $3.5 \%$ has affected them and $5.2 \%$ mentioned it may be affecting them. Out of these $62.5 \%$ said that the effect didn't remain for a long period, $23.1 \%$ is affected for long period and $14.4 \%$ may remain for long period.

Regarding the repeated use of epidural injection, $61.0 \%$ of the women used it in this survey thinks of using an epidural injection in the second birth, while $24.5 \%$ will not use it again, and $14.6 \%$ maybe they will be used again. The frequency of using epidural injection $78.4 \%$ of women used it once, $16.3 \%$ used twice, $4.1 \%$ used three times and $1.2 \%$ used more than three times. About $73 \%$ of women didn't use epidural more than one time, $5 \%$ of women used it more than once and they mentioned that they have suffered higher symptoms than the first injection, while only about $9 \%$ suffered lower symptoms than first use and 13\% have filled that they suffered the same symptoms in both times. $71.0 \%$ of women supported using the epidural injection in the first pregnancy and $29.0 \%$ did not. While $72.0 \%$ of used mothers advised other women to use epidural injection during labor and $28 \%$ did not advise any woman of using it. $87.0 \%$ of women agreed that the epidural injection use in labor have become widely common in the recent years and has a high demand, $2 \%$ disagreed in this and $11 \%$ mentioned it maybe became common.

In our research study as we mentioned earlier have two groups the first one who didn't use the epidural injection and the second one who used it. The percentage of women that used the epidural injection is $67.0 \%$ and who didn't use it is about $33.0 \%$. The main reasons of those who didn't use the epidural injection are panic and fear from the injection because it is given in the back, their knowing that the injection is harmful, a natural birth experience, and a sense of pain, the administration phase exceeded the expansion of more than $5 \mathrm{~cm}$, cesarean births, the injection cost did not recommend by the physician, unavailable epidural injection in the government hospital, and because they didn't want to try it.

\section{CONCLUSION}

Epidural analgesia appears to be common in use in Palestinian women and is a safe and effective way to lower the pain of labor. The study shows that the women who have taken the injection didn't have severe pain and symptoms after birth. The injection didn't affect seriously either mother or/ and fetus, and the high incident about the effect not prolong. Most women in this study recommended other women to use epidural analgesia injection during labor and they will use it again. The epidural analgesia found to be widely common in Palestinian women and the majority of women used it and the women want to use it again. As mentioned, the side effects of epidural analgesia on mother and child were found to be minor, but further research may be needed to evaluate rare but potentially severe adverse effects of epidural analgesia on women in labor and longterm neonatal outcomes. To the best of our knowledge, this is the first study about epidural analgesia in Palestinian women.

\section{REFERENCES:}

1. Melzack R. The myth of painless childbirth. Pain 1984; 321337.

2. Morgan BM, Bullpitt CJ, Clifton P, Lewis PJ. Analgesia and satisfaction in childbirth (the Queen Charlotte's 1000 mother survey). Lancet. 1982a; ii: 808-810.

3. Lowe NK. Pain and discomfort of labour and birth. J Obstet Gynaecol Neonatal Nurs. 1996; 25: 82-92.

4. Lowe NK. Differences in first and second stage labour pain between nulliparous and multiparous women. J Psychosom Obstet Gynecol. 1992; 13: 243-53.

5. Ranta P, Jouppila R. The intensity of labour pain in grand multiparas. Acta Obstet Gynecol Scand 1996; 75: 250-4.

6. Christiansen P, Klostergaard KM, Terp MR, Poulsen C, Agger AO, Rasmussen KL. Long-memory of labour pain. Ugeskrift for Laeger. 2002; 164(42):4927-9

7. Thornton JG. Reducing likelihood of instrumental delivery with epidural anaesthesia. Lancet 2001; 358(9275):2.

8. Anim-Somuah M., Smyth R., Cyna A., Cuthbert A. Epidural versus non-epidural or no analgesia for pain management in labour, (intervention review) Cochrane Database Syst. Rev. 2018; 5:6-34.

9. Rota A., Antolinib L., Colciagob E., Nespolic A., Borrellid E., Fumagalli S. Timing of hospital admission in labour: Latent versus active phase, mode of birth and intrapartum interventions. A correlational study. Women Birth. 2018; 31:313-318. doi: 10.1016/j.wombi.2017.10.001.

10. Canadian Institute of Health Information. Highlights of 20082009: Selected indicators describing the birthing process in Canada. [Accessed 2010 Sep 3]. Available from: http://www.cihi.ca.

11. Bucklin BA, Hawkins JL, Anderson JR, Ullrich FA. Obstetric anesthesia workforce survey: Twenty-year update. Anesthesiology. 2005; 103:645-653. 